\title{
Analisis Potensi Pendapatan Asli Daerah Sebagai Sumber Pembiayaan Pembangunan Daerah Sumatera Utara
}

\author{
Oleh : Ramadona Simbolon dan Sri Elviani *)
}

Intisari

Penelitian bertujuan untukmengetahui dan menganalisis Pendapatan Asli Daerah sebagai sumber pembiayaan pembangunan daerah Sumatera Utara, menganalisis potensi PendapatanAsli Daerah sebagai sumber pembiayaan pembangunan daerah yang dapat dikembangkan di Sumatera Utaradanmenganalisis dan menyusun strategi pengembangan potensi Pendapatan Asli Daerah sebagai sumber pembiayaan pembangunan daerah di Sumatera Utara.

Berdasarkan hasil analisis, ditemukan bahwa pajak daerah, retribusi daerah dan hasil kekayaan daerah yang dipisahkan secara simultan berpengaruh positif dan signifikan terhadap kemandirian fiskal. Secara parsial pajak daerah dan hasil kekayaan daerah yang dipisahkan berpengaruh terhadap kemandirian fiskal, sehingga retribusi daerah tidak berpengaruh terhadap kemandirian fiskal. Pajak Daerah merupakan sumber pendapatan yang memiliki kontribusi terbesar terhadap kemandirian fiskal, sedangkan retribusi daerah dan hasil pengelolaan kekayaan daerah kontribusinya masih kecil terhadap APBD Propinsi Sumatera Utara. Oleh karena itu perlu ditingkatkan peran BUMD dan retribusi daerah untuk meningkatkan penerimaan daerah dan mewujudkan kemandirian fiskal Propinsi Sumatera Utara.

Kata kunci : Pajak Daerah, retribusi daerah, hasil pengelolaan kekayaan daerah yang dipisahkan dan kemandirian fiskal.

PENDAHULUAN

\section{Latar Belakang}

Sebelum era reformasi harapan

pemerintah daerah untuk dapat

*) Dosen FE UISU Medan membangun daerah berdasarkan kemampuan dan kehendak daerah sendiri ternyata dari tahun ke tahun dirasakan semakin jauh dari kenyataan.

212 
Yang terjadi adalah ketergantuan fiskal dan subsidi serta bantuan pemerintah pusat sebagai wujud ketidakberdayaan Pendapatan Asli Daerah (PAD) dalam membiayai Anggaran Pendapatan dan Belanja Daerah (APBD).

Era reformasi memberikan peluang bagi perubahan paradigma pembangunan nasional dari paradigma pertumbuhan menuju paradigma pemerataan pembangunan secara lebih adil dan berimbang. Dikeluarkannya kedua UU No. 22 tahun 1999 dan UU No. 25 tahun 1999 tentangPerimbanganKeuanganAntaraP emerintahPusatdan Daerah memberikan implikasi yang sangat mendasar yang mengarah pada perlu dilakukannya reformasi sektor publik dan dipakainya paradigma baru dalam pengelolaan keuangan daerah. Dimensi reformasi sektor publik tersebut tidak saja sekedar perubahan format lembaga, akan tetapi mencakup pembaharuan alat-alat yang digunakan

*) Dosen FE UISU Medan untuk mendukung berjalannya lembaga-lembaga publik tersebut secara ekonomis, efisien, efektif, transparan, dan akuntabel sehingga cita-cita reformasi yaitu menciptakan good governance benar-benar tercapai.

Melihat kondisi sumber penerimaan di Sumatera Utara, ternyata Pendapatan Asli Daerah (PAD) belum bisa diharapkan untuk dijadikan tumpuan dalam mencukupi kebutuhan dana untuk pengeluaran daerah. Untuk menghindari persoalan dalam era desentralisasi pada masa mendatang, Pemerintah Daerah Provinsi Sumatera Utara perlu melakukan upaya-upaya yang serius dalam rangka meningkatkan kemampuan keuangan daerah yang bersumber dari PAD. Kondisi Pendapatan Asli Daerah di Sumatera Utara ditunjukkan dengan kontribusi Pendapatan Asli Daerah hanya sekitar $25 \%$ dari penerimaan daerah Sumatera Utara.

DIY Y YII' Vol. XV No. 1 Edisi Jan - April 2017 
Sejalan hal tersebut, makaperlu dilakukan Kajian Pengembangan

Potensi PendapatanAsli Daerah SebagaiSumber

Pembiayaan

Pembangunan Daerah Sumatera Utara.

Penelitian ini bertujuan untuk menguji dan menganalisis kemampuan keuangan daerah untuk membiayai pembangunan daerah. Ciri utama yang menunjukkan suatu daerah otonom harus memiliki kewenangan dan kemampuan untuk menggali sumbersumber keuangannya sendiri, mengelola dan menggunakan keuangan yang cukup memadai untuk membiayai penyelenggaraan pemerintahan daerahnya. Ketergantungan kepada bantuan pusat harus seminimal mungkin, sehingga PAD khususnya pajak menjadi bagian sumber keuangan terbesar (Koswara, 1999). Untuk meningkatkan potensi sumber-sumber pembiayaan pembangunan daerah atau juga biasa disebut dengan Pendapatan Asli Daerah (PAD), ada beberapa faktor

*) Dosen FE UISU Medan yang perlu diberdayakan diantaranya adalah investasi, obligasi dan PDRB perkapita. Untuk menggali potensi lokal dan meningkatkan kinerja keuangan dalam rangka mewujudkan kemandirian daerah pada pelaksanaan otonomi daerah terletak pada kemampuan keuangan daerah untuk membiayai penyelengaraan pemerintahannya, sehingga sudah sewajarnya apabila PAD dijadikan salah satu barometer dalam pelaksanaan otonomi daerah. Masalahnya proporsi penerimaan yang berasal dari PAD Provinsi jumlahnya kecil, sehingga terjadi ketidakseimbangan keuangan daerah (fiscal gap) antara kemampuan daerah (fiscal capacity) dan kebutuhan daerah (fiscal need).

\section{Tujuan Penelitian}

Tujuan penelitian ini adalah untuk :

a. Mengetahui danmenganalisisPendapatanAsli Daerah sebagaisumberpembiayaan 
pembangunan daerah Sumatera Utara.

b. Menganalisis potensi PendapatanAsli Daerah sebagaisumber pembiayaan pembangunan daerah yang dapat dikembangkan di Sumatera Utara.

c. Menganalisis dan menyusun strategi pengembangan potensi Pendapatan Asli Daerah sebagai sumber pembiayaan pembangunan daerah di Sumatera Utara

\section{METODE PENELITIAN}

\section{Jenis Penelitian}

Jenis penelitian yang digunakan dalam penelitian ini adalah jenis penelitian asosiatif dengan hubungan kausal atau sebab akibat dan penelitian deskriptif kualitatif. Variabel-variabel yang diteliti dalam penelitian ini adalah pajak daerah, retribusi daerah, hasil pengelolaan kekayaan daerah yang dipisahkan, dan kemandirian fiskal.

\section{Jenis dan Sumber Data}

Penelitian ini menggunakan jenis data sekunder (time series) selama periode tahun 2005 s/d 2012.Data yang diperoleh berupa data realisasi penerimaan Anggaran Pendapatan Belanja Daerah (APBD) atau Total Penerimaan

Sumber data lainnya berupa buku-buku laporan tahunan beberapa terbitan seperti : Statistik Keuangan Pemerintah Daerah Sumatera Utara, PDRB Sumatera Utara dan jurnal-jurnal beberapa terbitan yang dapat diperoleh diberbagai instansi.

\section{Metode Pengumpulan data}

Metode pengumpulan data adalah melalui studi pustaka. Data dalam penelitian ini diperoleh dalam bentuk yang sudah jadi dari Kantor Gubernur Provinsi Sumatera Utara. Data yang berbentuk tahunan diolah dalam bentuk triwulanan untuk menyeragamkan periode masing-masing variabel. 


\section{Teknik Analisis Data}

Teknik analisis yang digunakan untuk menjawab tujuan dalam penelitian ini adalah analisis regresi berganda dan dikombinasikan dengan metode analisis deskriptif.

\section{AnalisisRegresi Linear Berganda}

Persamaan regresi linier berganda dalam penelitian ini adalah sebagai berikut :

$D K F=\alpha+\beta_{1} P D+\beta_{2} R D+\beta_{3} H P K D+e$ Keterangan :

DKF : Derajat Kemandirian Fiskal

PD : Pajak Daerah

RD : Retribusi Daerah

HPKD : Hasil Pengelolaan Kekayaan Daerah Dipisahkan

$\alpha \quad$ : Konstanta.

$\beta \quad$ : Koefisien Regresi.

e : Residual

*) Dosen FE UISU Medan

\section{Analisis Deskriptif}

Selain analisis regresi berganda, penelitian ini juga menggunakan analisis deskriptif. Analisis deskriptif ini digunakan untuk mengetahui dan menganalisis besarnyaPAD yang terdiridari Pajak Daerah, Retribusi Daerah, Hasil Kekayaan Pemerintah Daerah yang dipisahkan dan selanjutnya menyusun strategi pengembangan potensi-potensi penerimaan daerah dalam meningkatkan PAD yang akan digunakan untuk pembangunan daerah.

\section{PEMBAHASAN}

Sumber-sumber

Pembiayaan

Pembangunan Provinsi Sumatera Utara

Hasil uji F menunjukkan bahwa pajak daerah, retribusi daerah, danhasilkekayaandaerah yang dipisahkan berpengaruh terhadap derajat kemandirian fiskal. Hal ini terlihat dari nilai $F$ hitung $34,274>2,51$ dan signifikan karena nilai sig. sebesar 216

DIn YIII Vol. XV No.1 
$0.000<0.05$. Hasil penelitian ini menunjukkan bahwa sumber-sumber pembiayaan keuangan Pemerintah Provinsi Sumatera Utara, khususnya PAD berasal dari pajak daerah, retribusi daerah dan hasil pengelolaan kekayaan daerah yang dipisahkan. Hal tersebut dibuktikan dengan struktur APBD Pemerintah Provinsi Sumatera Utara yang beberapasumber penerimaannya terdiri dari pajak daerah, retribusi daerah, danhasilkekayaandaerah yang dipisahkan.

Berdasarkan hasil analisa di atas, maka Provinsi Sumatera Utara perlu meningkatkan penerimaan khususnya dari PAD yang terdiri dari pajak daerah, retribusi daerah, dan hasil pengelolaan kekayaan daerah yang dipisahkan sehingga dapat meningkatkan kemampuan keuangannya dan menciptakan kemandirian fiskal bagi Provinsi Sumatera Utara. Selain itu Pemerintah Provinsi Sumatera Utara perlu

*) Dosen FE UISU Medan mengalokasikan belanja sesuai dengan prioritas dan untuk pembangunan, sehingga tercipta kesempatan untuk bekerja bagi masyarakat dan meningkatkan penghasilan masyarakat serta kesejahteraannya.

\section{Pajak Daerah (X1) dan Kemandirian Fiskal (Y)}

Hasil uji secara parsial dengan menggunakan uji t menunjukkan bahwa pajak daerah berpengaruh terhadap derajat kemandirian fiskal. Hal ini terlihat dari nilai t hitung $10,129>1,714$ dan signifikan karena nilai sig. sebesar $0.000<0.05$. Hasil penelitian ini menunjukkan bahwa pajak daerah merupakan sumber yang digunakan untuk membiayai belanja rutin dan belanja pembangunan Pemerintah Provinsi Sumatera Utara. Jika dilihat dari nilai koefisien regresinya yaitu sebesar 1,100. Hal ini menunjukkan bahwa pengaruh pajak daerah terhadap kemandirian fiskal adalah positif dan signifikan yang berarti

DIN YIIY Vol. XV No. 1 


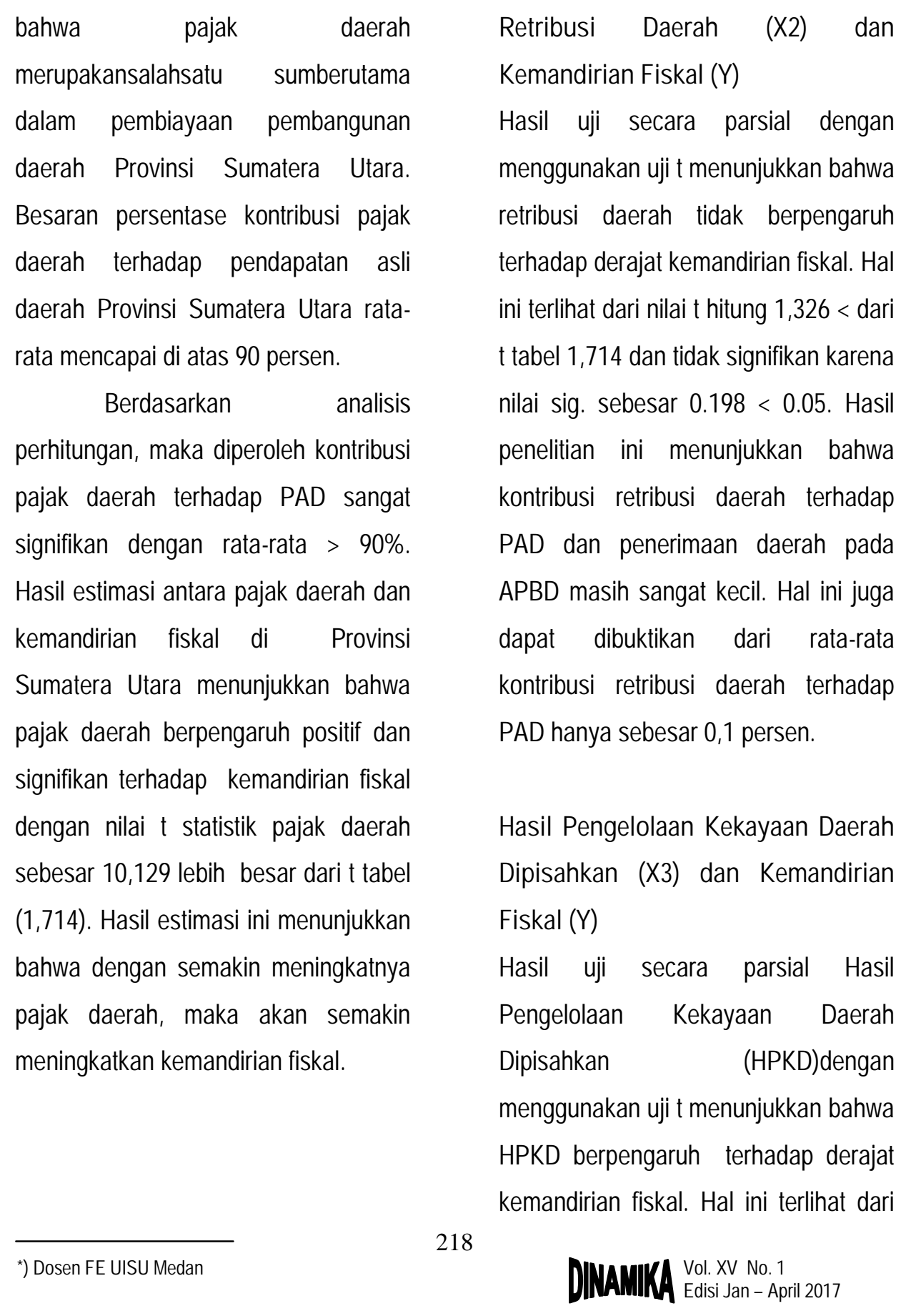


nilai t hitung 3,539 > 2,51 dan signifikan karena nilai sig. sebesar $0.000<0.05$. Hasil penelitian ini menunjukkan bahwa HPKD merupakan sumber Pendapatan Asli Daerah potensil yang dapat digunakan untuk membiayai belanja Pemerintah Provinsi Sumatera Utara. Jika dilihat dari nilai koefisien regresinya yaitu sebesar 0,251 , maka kontribusi HPKD Provinsi Sumatera yang ada saat ini masih belum maksimal.

Berdasarkan analisis perhitungan, terlihat bahwa rata-rata kontribusi Hasil Pengelolaan Kekayaan Daerah Dipisahkan (HPKD) terhadap PAD rata-rata hanya 0,5 persen. Hal ini membuktikan bahwa kinerja BUMD belum maksimal, sehingga belum mampu untuk meningkatkan PAD secara signifikan. Hal ini tentunya membutuhkan strategi dan solusi dalam pemberdayaan BUMD, sehingga dapat meningkatkan labanya dan berkontribusi secara signifikan terhadap PAD dan menjadi salah satu sumber

*) Dosen FE UISU Medan utama pembiayaan pembangunan daerah Provinsi Sumatera Utara sehingga dapat meningkatkan kesejahteraan masyarakat.

\section{Analisis Potensi Sumber-Sumber Pembiayaan Pembangunan Daerah} Sumatera Utara

Berdasarkan analisis dalam penelitian ini, maka terlihat bahwa sumbersumber penerimaan daerah saat ini hanya pajak daerah yang memberikan kontribusi terbesar, namun secara umum sumber-sumber penerimaan daerah tersebut yang akan digunakan untuk pembiayaan pembangunan daerah di Provinsi Sumatera Utara masih belum optimal. Hal ini terlihat dari kontribusi masing-masing variabel sumber-sumber pembiayaan pembangunan tersebut diantaranya retribusi daerah hanya sebesar 0,1 persen, HPKD sebesar 0,5 persen, dana bagi hasil sebesar 0,1 persen, dana alokasi umum sebesar 0,1 
persen, dana alokasi khusus sebesar

0,1 persen, dan pendapatan lain-lain yang sah hanya sebesar 0,05 persen.

\section{Strategi Pengembangan Sumber- Sumber Pembiayaan Pembangunan Daerah Provinsi Sumatera Utara}

Berdasarkan analisis statistik terkait pengaruh masing-masing variabel terhadap kemandirian fiskal dan analisis secara deskriptif terhadap kelemahan-kelemahan dan belum optimalnya sumber-sumber pembiayaan pembangunan daerah Provinsi Sumatera Utara, maka diperlukan solusi dan strategi dalam peningkatan sumber-sumber penerimaan daerah tersebut sehingga dapat dijadikan sebagai sumber pembiayaan pembangunan daerah Provinsi Sumatera Utara dan menciptakan kemandirian fiskal. Beberapa strategi dalam peningkatan penerimaan daerha tersebut akan diuraikan sebagai berikut di bawah ini.

*) Dosen FE UISU Medan
Strategi Pengembangan Penerimaan Pajak Daerah

Berdasarkan data Penerimaan

Pajak Daerah Propinsi Sumatera Utara terjadi peningkatan nilai masing-masing sumber penerimaan pajak daerah setiap tahunnya, khususnya untuk pajak kenderaan bermotor, bea balik nama kenderaan bermotor dan pajak bahan bakar kenderaan bermotor. Oleh karena itu Peningkatan penerimaan daerah dari pajak daerah yang ada di Provinsi Sumatera Utara dalam meningkatkan potensi sumber penerimaan daerah yang akan digunakan untuk membiayai pembangunan daerah dapat dilakukan sebagai berikut :

1. Menaikkan tarif pajak untuk Pajak Kenderaan Bermotor, khususnya Sedan, Jeep, Station Wagon, Truck, Pick Up (Tidak Umum), Sepeda Motor, Scooter.

2. Meningkatkan penjualan kenderaan di atas air, melalui pemberdayaan pariwisata yang menggunakan 
kenderaan di atas air, sehingga dapat meningkatkan penjualan kenderaan di atas air, serta meningkatkan penerimaan pajak kenderaan di atas air.

Selain itu strategi peningkatan pajak juga dapat dilakukan dengan peningkatan investasi, sehingga dapat meningkatkan kesejahteraan masyarakat untuk mampu meningkatkan daya beli masyarakat. Besarnya kontribusi pajak daerah Provinsi Sumatera Utara terhadap kemandirian fiskal, maka Pemerintah Provinsi Sumatera Utara perlu melakukan peningkatan pajak secara terus-menerus. Salah satunya adalah dengan meningkatkan investasi, dimana dalam jangka panjang investasi akan meningkatkan potensi output dan mendorong pertumbuhan ekonomi secara terus-menerus baik melalui penanaman modal dalam negeri (PMDN) maupun penanaman modala asing (PMA).

Investasi merupakan suatu faktor krusial bagi kelangsungan proses pembangunan ekonomi (suistanable development) atau pertumbuhan ekonomi jangka panjang. Pembangunan ekonomi melibatkan kegiatan-kegiatan produksi (barang dan jasa) di semua sektor-sektor ekonomi. Dengan adanya kegiatan produksi, maka terciptalah kesempatan kerja dan pendapatan masyarakat meningkat, yang selanjutnya menciptakan/ meningkatkan permintaan di pasar. Pasar berkembang dan berarti juga volume kegiatan produksi, kesempatan kerja dan pendapatan dalam negeri meningkat dan seterusnya, maka terciptalah pertumbuhan ekonomi.

Dalam pembangunan daerah Provinsi Sumatera Utara diperlukan berbagai fasilitas modal. Pemerintah daerah perlu memfasilitasi berbagai aktivitas peningkatan perekonomian, salah satunya dengan membuka kesempatan berinvestasi.

DYuy Vol. XV No.1 Edisi Jan - April 2017 


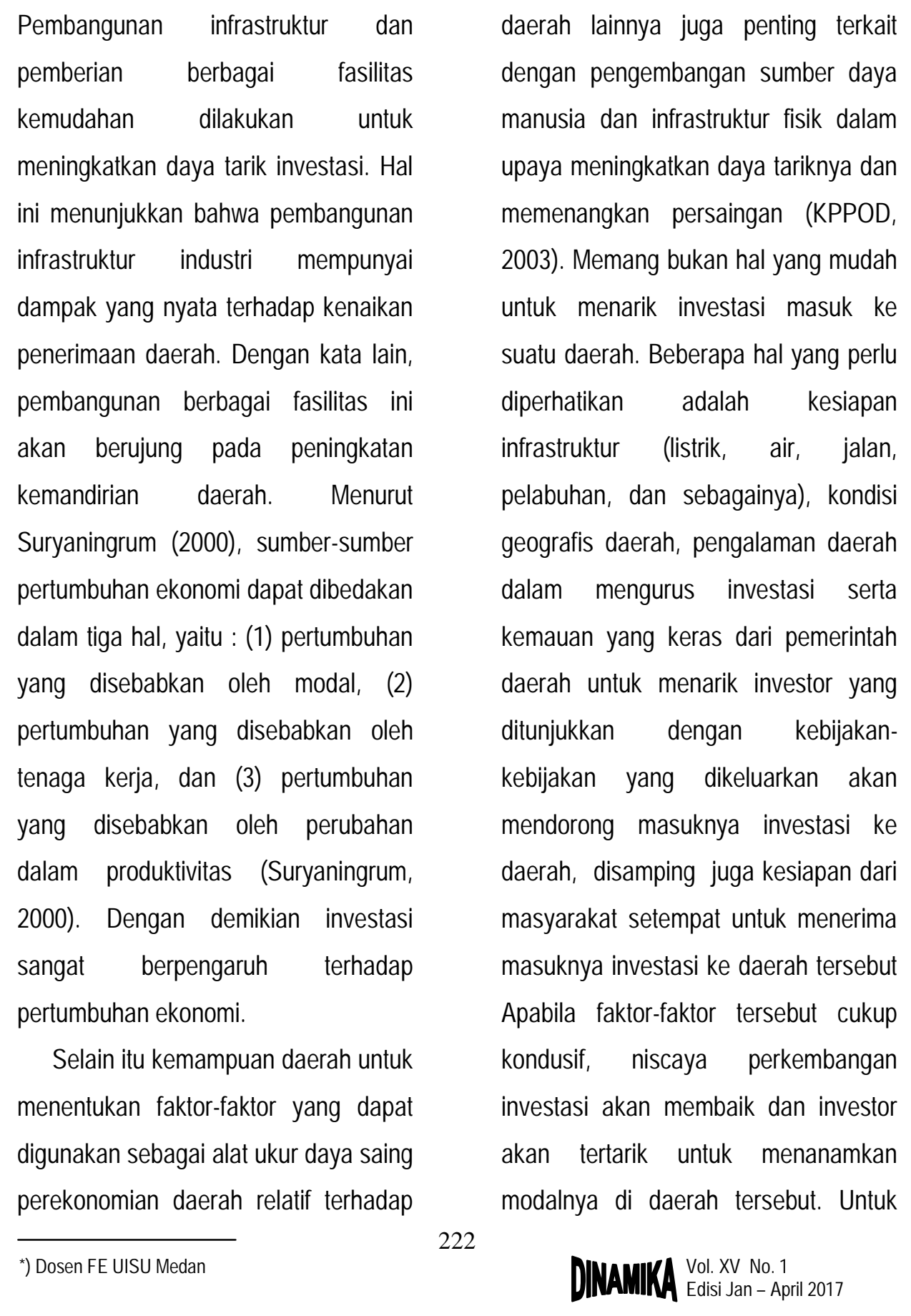


meningkatkan peluang berinvestasi di Provinsi Sumatera Utara, maka perlu adanya suatu strategi dari pemerintah daerah berupa reformasi mendasar berkaitan dengan perbaikan iklim bisnis dan investasi, yaitu :

1. Reformasi pelayanan investasi. Otonomi daerah dan desentralisasi fiskal telah memberikan peran pemerintah daerah dalam hal prosedur aplikasi dengan terlebih dahulu investor harus mendapatkan beberapa persetujuan, perizinan dan restu BKPMD untuk tahap awal diantaranya (JETRO, 2003).

2. Koordinasi antar tingkat pemerintah baik vertikal maupun horizontal. Beberapa pemerintah daerah telah menerapkan sistem Unit Pelayanan Terpadu (UPT) dalam pelayanan perizinan. Sistem ini ditujukan untuk menyederhanakan birokrasi perizinan. Beberapa pemerintah daerah telah menerapkan Sistem Perizinan Satu Atap (SINTAP). Hal ini diperlukan karena dengan

*) Dosen FE UISU Medan menciptakan pelayanan perizinan dan investasi maka permohonan perizinan dapat diproses di satu tempat sehingga birokrasi menjadi lebih pendek, cepat dan efisien.

3. Tiga hal utama yang diinginkan investor, yaitu : (1) penyederhanaan sistem perizinan; (2) penurunan berbagai pungutan yang tumpang tindih; (3) transparansi biaya perizinan.

4. Reformasi peraturan dapat dimulai oleh pemerintah daerah

\section{Strategi Pengembangan Retribusi} Daerah

Berdasarkan data Jumlah sumber penerimaan retribusi daerah yang ada terjadi peningkatan nilai masing-masing sumber penerimaan retribusi daerah setiap tahunnya, khususnya untuk retribusi jasa umum dan retribusi jasa usaha. Oleh karena itu Peningkatan penerimaan daerah dari retribusi daerah yang ada di Provinsi Sumatera Utara dalam 


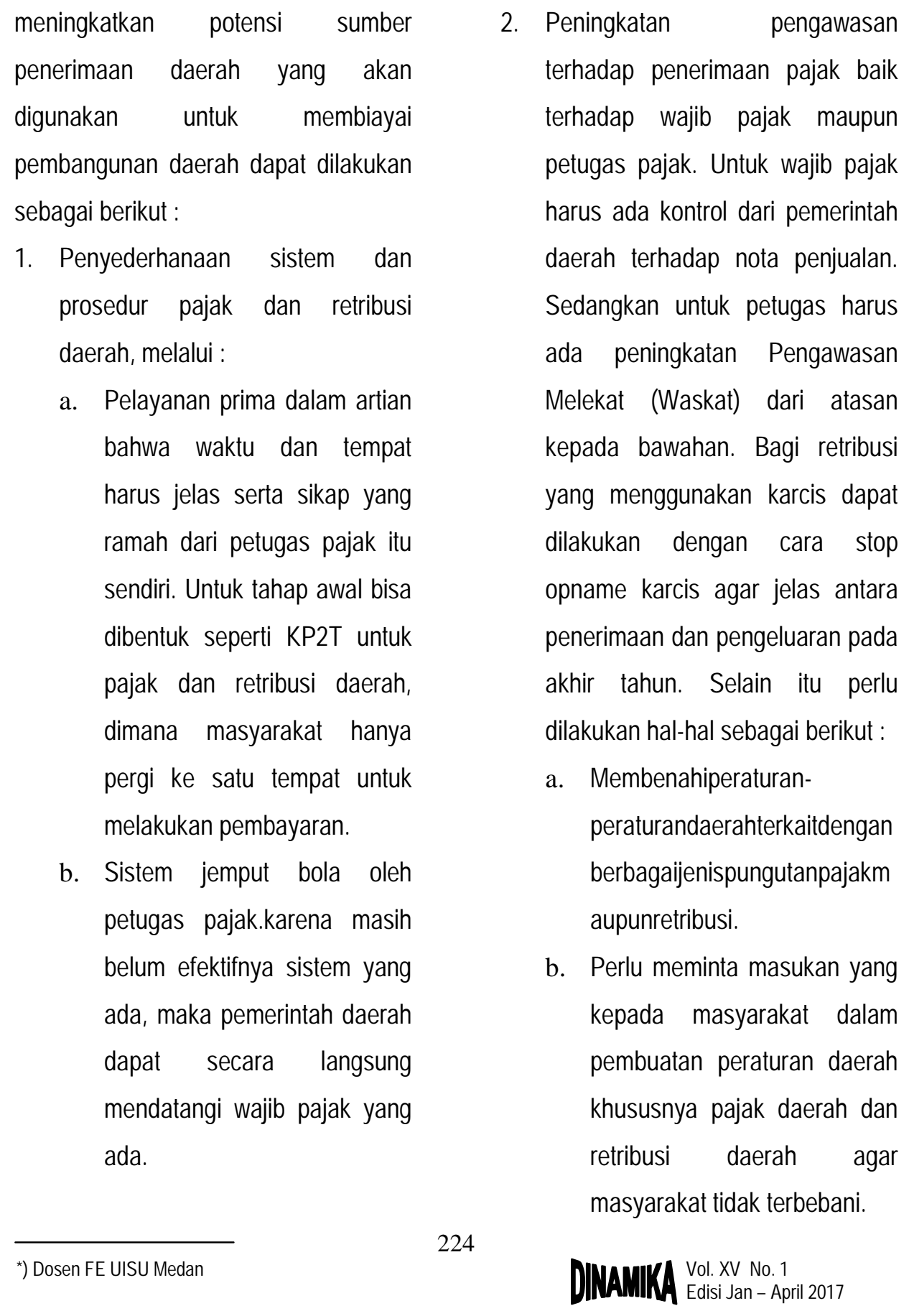


c. Peningkatan sumber daya manusia, dalam hal ini bisa berupa pemberian pelatihan bagi petugas pajak (pembinaan tersebut dilakukan oleh atasan).

\section{Strategi Pengembangan Hasil Pengelolaan Kekayaan Daerah Dipisahkan (HPKD)}

Berdasarkan data Jumlah sumber penerimaan HPKD yang ada terlihat bahwa penerimaan HPKD yang ada di Provinsi Sumatera Utara, masih belum signifikan. Hal itu terlihat dari kontribusi HPKD belum signifikan terhadap PAD. Peningkatan penerimaan dari HPKD dapat dilakukan dengan berbagai langkah dan tindakan yang sifatnya strategis dalam rangka meningkatkan sumber-sumber pembiayaan pembangunan daerah Provinsi Sumatera Utara adalah sebagai berikut :

1. Mempertahankan BUMD yang kinerjanya baik seperti PT Bank

*) Dosen FE UISU Medan
Sumut. Sumber HPKD terbesar adalah penerimaan dari PT Bank Sumut, dimana pada Tahun 2011 dan 2012 mencapai Rp 200 milyaran. Jika seluruh BUMD yang ada di Provinsi Sumatera Utara memiliki kinerja seperti PT Bank Sumut, maka penerimaan HPKD dari seluruh BUMD akan mencapai trilyunan rupiah. Hal ini akan meningkatkan kontribusi HPKD terhadap PAD secara signifikan.

2. Membentuk Undang-Undang tentang BUMD, setelah dicabutnya Undang-Undang No. 5 Tahun 1962 tentang BUMD, sehingga BUMD memiliki payung hukum yang jelas dalam melaksanakan operasionalnya dan dalam Undang-Undang tersebut, BUMD harus memiliki kebebasan dalam mengembangkan operasinya serta jenis usahanya.

3. Meningkatkan ataupun menghentikan BUMD yang kinerjanya buruk, karena hanya 
akan menambah beban

Pemerintah Provinsi Sumatera

Utara, yang dapat digantikan

BUMD yang baru dengan bidang usaha yang dapat menghasilkan laba cukup besar, seperti dalam bidang kontruksi maupun bidang jasa tol dan lainnya.

4. Menempatkan orang-orang yang profesional yang memiliki skill dan kompetensi sesuai bidang usaha BUMD yang digarap. Selain itu peningkatan kompetensi dan profesionalisme direksi beserta stafnya dalam menjalankan perusahaan sebagai usaha komersial murni yang mengutamakan pertimbangan efesiensi dan pencapaian laba usaha yang memadai. Direksi dan staf yang ditempatkan di BUMD haruslah orang-orang yang mempunyai jiwa dan semangat wiraswasta/entrepeneurship dalam menjalankan operasional usaha.

*) Dosen FE UISU Medan
5. Pemberian wewenang dan pendelegasian kebijakan yang lebih besar dan luas oleh pimpinan daerah kepada BUMD dalam operasionalnya. BUMD tidak boleh dijadikan sapi perah atau kereta politik bagi kepentingan birokrat maupun partai politik. Hal ini harus sejalan dengan tujuan BUMD tersebut didirikan adalah tetap profit oriented untuk menambah PAD.

6. Mengatasi kelemahan internal dengan penetapan kembali core bisnis, likuidasi unit usaha yang selalu merugi. Memperbaiki sistem manajemen dengan cara memperluas pangsa pasar dengan mempertahankan pasar lama dan mencari pasar baru, mengadopsi teknik produksi baru yang lebih efesien dan efektif serta memperbaiki koordinasi antar BUMD dalam industri hulu dan hilir. Memaksimumkan peluang eksternal berupa upaya kerjasama 
yang saling menguntungkan dengan perusahaan sejenis atau yang ada keterkaitan. Bentuk kerja sama bisa berupa joint venture atau bentuk kerja sama lainnya.

\section{KESIMPULAN}

Berdasarkan analisis dan pembahasan yang telah dikemukakan sebelumnya maka dapat ditarik kesimpulan sebagai berikut :

1. Pajak daerah berpengaruh positif dan signifikan terhadap kemandirian fiskal Provinsi Sumatera Utara, dimana kontribusi pajak daerah terhadap Pendapatan Asli Daerah (PAD) Provinsi Sumatera Utara dan total penerimaan APBD yang cukup signifikan.

2. Retribusi daerah tidak berpengaruh terhadap kemandirian fiskal Provinsi Sumatera Utara, hal ini terlihat dari kontribusi retribusi daerah yang tidak signifikan

*) Dosen FE UISU Medan terhadap PAD dan penerimaan daerah dalam APBD.

3. Hasil Pengelolaan Kekayaan Daerah yang Dipisahkan (HPKD) berpengaruh terhadap kemandirian fiskal Provinsi Sumatera Utara, namun kontribusinya terhadap PAD dan total penerimaan daerah masih sangat kecil.

4. Sumber-sumberpembiayaan pembangunan Provinsi Sumatera Utara masih bertumpu pada pajak daerah, dana alokasi umum dan dana alokasi khusus, dimana sumber-sumber penerimaan daerah Provinsi Sumatera Utara belum optimal sehingga belum dapat menciptakan kemandirian fiskal. 


\section{DAFTAR KEPUSTAKAAN}

Bachrul Elmi, 2002. Keuangan Pemerintah Daerah Otonomi di Indonesia. UI Press, Jakarta.

Badan Pusat Statistik Sumatera Utara, 2011. Sumatera Utara Dalam Angka Tahun 2011.

Direktorat Pengembangan Kerjasama Pemerintah dan Swasta Bappenas. 2008. KPS Kemitraan Prasarana dan Sarana. Mengamankan Investasi Jalan tol.

Fabozzi, F., 2004.Bond Market, Analysis and Strategies. 5th eds.; Prentice Hall International Editions.

Fong, H. Gifford and F. J. Fabozzi, 1985.Fixed Income Portfolio Management. Dow Jones, Irwin, Illinois, USA.

Fabozzi, F.J., Martellini, L. And Philippe Priaulet, 2006. Advanced Bond Portfolio Managemen t: Best Practices in Modelling and Strategies. John Wiley and Sons Inc.

Kementerian Keuangan RI, 2008. Buku Penyelenggaraan Pemerintahan dan Pembangunan Daerah.

Kementerian Keuangan RI, 2009. Permenkeu No.171.1/PMK.07/2008 tentang Penetapan Alokasi Dana Alokasi Khusus Tahun Anggaran 2009. Laporan Penelitian Mekanisme dan Penggunaan DAK, Lembaga Penelitian Smeru.

Peraturan Pemerintah Nomor 54 Tahun 2005 tentang Pinjaman Daerah.

Peraturan Pemerintah Nomor 2 Tahun 2006 tentang Tata Cara Pengadaan Pinjaman dan/atau Penerimaan Hibah serta Penerusan Pinjaman dan/atau Hibah Luar Negeri

*) Dosen FE UISU Medan 
Peraturan Menteri Negara Perencanaan Pembangunan Nasional/Kepala Bappenas No. 005/M.PPN/06/2006 tentang Tatacara Perencanaan dan Pengajuan Usulan serta Penilaian Kegiatan yang Dibiayai dari Pinjaman dan/atau Hibah Luar Negeri;

Peraturan Menteri Keuangan Nomor 95/PMK.02/2007 tentang Pedoman Pelaksanaan dan Mekanisme Pemantauan Defisit Anggaran Pendapatan dan Belanja Daerah dan Pinjaman Daerah.

UNDP. 1997. Developing Capacity ForEfective Governance. Workshop for UNDP Country Offices.

UU Nomor 17, Tahun 2003 tentang Keuangan Negara.

UU Nomor 1, Tahun 2004 tentang Perbendaharaan Negara.

UU Nomor 25 Tahun 2004 tentang Sistem Perencanaan Pembangunan Nasional.

UU Nomor 32 Tahun 2004 tentang Pemerintahan Daerah.

UU Nomor 33 Tahun 2004 tentang Perimbangan Keuangan Antara Pemerintah Pusat dan Pemerintahan Daerah.

*) Dosen FE UISU Medan 